\title{
Some reflections on principles of Isthmo-Colombian Amerindian ontologies
}

\author{
Ernst Halbmayer
}

\begin{abstract}
:
The search for ontological principles specific for the Isthmo-Colombian region developed slowly during the last decade and started from ethnographic data and anthropological experiences which diverge in specific ways from the ideal-typical ontological notions of animism or analogism. The paper presents reflections on a set of ontological principles, which - based on the current state of analysis - allow to characterize a variety of Isthmo-Colombian socio-cosmologies in non-essentialist terms and in delineation to Amazonian animism, which became used as interpretative frame also for contemporary indigenous groups further north. Thus, rather than proposing the existence of a specific and rigid Isthmo-Colombian ontology I will try to summarize a number of basic principles along which local socio-cosmologies differ from the great ontological schemes like animism and analogism. By making some ontological links between the IsthmoColombian area and Mesoamerica visible the paper invites to rethink local principles in ontological terms, while avoiding the imposition of theoretically attractive, but only partially fitting ontological schemata, which may cause selective misreadings and biased interpretations of local ontological principles.
\end{abstract}

Keywords: Isthmo-Colombian Area, ontological principles, Amazonia, Mesoamerica

\section{Resumen:}

ALGUNAS REFLEXIONES SOBRE LOS PRINCIPIOS ONTOLÓGICOS AMERINDIOS

ISTMO-COLOMBIANOS.

Durante la última década la búsqueda de principios ontológicos característicos para la región istmo-colombiana se desarrolló paulatinamente y empezó con los datos etnográficos y experiencias antropológicas que discrepan específicamente de las nociones ideales del animismo o analogismo. El artículo despliega las reflexiones sobre un conjunto de principios ontológicos que, a partir del estado actual de análisis, permiten caracterizar las variedades istmo-colombianas de sociocosmologías en términos no esencialistas y en cuanto a la descripción del animismo amazónico, que se convirtió en un marco interpretativo también para los grupos indígenas contemporáneos situados más al norte. De este modo, en lugar de proponer la existencia de una ontología rígida y específica istmo-colombiana, intentaré resumir la presencia de una serie de principios básicos en la que las sociocosmologías locales muestran diferencias con respecto a los grandes esquemas ontológicos como lo son el animismo y el analogismo. Exhibiendo varios vínculos ontológicos entre el área istmo-colombiana y la región de Mesoamérica, el presente artículo invita a repensar los principios locales utilizando los términos ontológicos. Al mismo tiempo se evita de imponer los esque-

Ernst Halbmayer • Institute for Social Anthropology and the Study of Religions, Philipps-Universität Marburg, email: halbmaye@uni-marburg.de

(D) https://orcid.org/0000-0002-7132-5158 
mas ontológicos que parecen ser teóricamente atractivos, pero que solo parcialmente se pueden ajustar a las realidades locales. De este modo se pretende eludir lecturas equivocadas o interpretaciones sesgadas de los principios ontológicos locales.

Palabras claves: Area Istmo-Colombiana, principios ontologicas, Amazonia, Mesoamerica

\section{Introduction}

The search for principles of Isthmo-Colombian ontologies, to which this paper contributes, is inspired by the broader anthropological debates on Amerindian ontologies and multinaturalism (Descola 2013; Viveiros de Castro 1998) and a certain gap in socio-anthropological research on the Isthmo-Colombian area. Since Clark Wissler's (1922: 229-231) and Paul Kirchhoff's (1943) proposal of a "Chibcha Area" and Julian Steward's studies on the "Circum-Caribbean Area" (Steward 1948; Steward and Faron 1959), anthropology has failed to offer a new comparative understanding of the region. The search for a comparative view on the region has rather been led either by archaeology - for example, by the archeological studies of Haberland (1957) and Willey (1971) on the "intermediate Area", by John Hoopes and Oscar Fonseca on the "Isthmo-Colombian Area" (2003) or Broekhoven, Geurds and Hofman's research on the "Greater Caribbean Area" (Geurds and van Broekhoven 2010; Hofman et al. 2010) - or the linguistic studies of Adolfo Constenla Umaña $(1991,2012)$.

In Julian Steward's cultural-ecological understanding, the so-called "Circum-Caribbean Zone" was defined most importantly by the existence of chiefdoms. After these chiefdoms ${ }^{1}$ had disappeared, the contemporary, transformed, and numerically reduced groups resembled the cultures of the Amazonian Tropical Forest Area. For this reason, since the 1950s the theoretical framework for their study was - at least in the region's lowlands - provided by Amazonian anthropology.

Even if aspects of social differentiation and complexity have disappeared over the last 500 years and contemporary local economies seem to resemble those of the Tropical Forest Culture, a closer inspection brings economic as well as sociocosmological or ontological differences to the fore. In economic terms the region was characterized by elaborate trade and what is more, by the existence of markets (Kurella 1993, 1998), irrigation systems. and intensive cultivation on raised fields. Some regions like the Sierra Nevada de Santa Marta (Kogi, Ika, Wiwa) even today are characterized, as has been described for the Andes (Murra 1972), by the vertical control of various ecological levels and by the systematic exchange of products from such levels among different groups, like in the Sierra Nevada del Cocuy among the

1 For more contemporary reflections on chiefdoms of the area see, for example, Drennan and Uribe 1987; Helms 1980, 1992; Keegan and MacLachlan 1989; Drennan 1995; Redmond 1998; Langebaek 2005; Oyuela-Caycedo 2008. 
U'wa (Falchetti 2001; Osborn 2009). Basic agricultural techniques included putrefaction, incineration, and fallowing (Niño Vargas 2018, 2020b).

In socio-cosmological terms, I argue, there are some striking differences from the ideal-typical Amazonian animism or multinaturalism, as defined by Viveiros de Castro (1998) or Philippe Descola (2013). Thus, the region has the potential to make an important contribution to the debate about the plurality of Lowland South American ontological schemata, establishing links to Mesoamerican and Andean schemata, and providing empirical evidence for cosmological schemata that go beyond unified theories of Amazonian sociality (Viveiros de Castro 2001). In the South American lowlands such alternatives have been discussed in different terms for Arawak-speaking groups (Hill and Santos-Granero 2002), the Northwest Amazon and the Upper Xingú, or Carib-speaking groups (Halbmayer 2012, 2010), while the discussion has been lacking reflections on the northwestern part of the continent and Lower Central America so far.

The principles I will present have emerged from a series of conferences and discussions with fellow anthropologists working ethnographically in the area between Mesoamerica, the Andes, and the Amazon. Mònica Martínez Mauri of the University of Barcelona, with whom I organized several workshops on the topic ${ }^{2}$, deserves special mention, as well as Juan Camilo Niño Vargas of the Universidad de los Andes in Bogotá, with whom I discussed the principles of Chibchan ontologies intensively on various occasions. Results have been published in the book Amerindian Socio-Cosmologies between the Andes, Amazonia and Mesoamerica: Toward an Anthropological Understanding of the Isthmo-Colombian Area (Halbmayer 2020a), which presents the outcomes of a conference organized in Lyon in $2017^{3}$ and a special issue of the Colombian Journal Tabula Rasa that deals specifically with modes of relations in the area (Martínez Mauri und Halbmayer 2020). The current paper builds upon and adds to these insights.

2 Among others: the workshop "Between the Andes, Amazonia and Mesoamerica: Cultures and Ontologies of the Intermediate Zone" at the 6th Meeting of German-speaking researchers on South America, Mesoamerica and the Caribbean (Bonn, 2013), the symposium "Cultures and Ontologies of the Intermediate Zone: between the Andes, Amazonia and Mesoamerica" at the 55th International Congress of Americanists in San Salvador (2015) and the panel on "Gifts, Exchanges and Other Modes of Relations among the Contemporary Indigenous Societies of the Isthmo-Colombian Area" at the 56th International Congress of Americanists in Salamanca (2018).

3 The book is the outcome of a Senior Fellowship of the European Institutes for Advanced Study (EURIAS), a program of the European Commission's Marie Skłodowska-Curie Actions. The fellowship allowed me to stay at the Collegium de Lyon and work on the project "Amerindian Socio-Cosmologies in North-Western South America: Toward an integrated Analysis across Chibcha, Carib, and Arawakan Language Families" during the academic year of 2015/16. With the support of the Collegium de Lyon - Institute for Advanced Studies; the French Network of Institutes for Advanced Studies (RFIEA); the Laboratoire Dynamics of Language (DDL) - CNRS-Université Lumière Lyon 2; and the Department of Cultural and Social Anthropology, Marburg University, I was able to organize the workshop "Socio-Cosmologies in the Isthmo-Colombian Area: Toward an Understanding of Relationships among Chibchan and Neighboring Cultures and Languages", which took place in Lyon from 25 to 27 January 2017. 
I will summarize some basic principles in terms of which local socio-cosmologies differ from the great ontological schemes - like animism, analogism, or totemism - proposed in the literature (Descola 2013). These principles serve to establish a dynamic and flexible characterization of the Isthmo-Colombian region in terms of Wittgenstein's family resemblances or Rodney Needham's polythetic classification (Needham 1975; Osborn 1988). The identified elements are characteristic of the region, but not all of them are necessarily present in each specific case. And the single principles are not necessarily exclusive to the Isthmo-Colombian area. Several of them are likely to exist also elsewhere, for example in Mesoamerica, the Andes, or Amazonia in different configurations and along with other principles. In attempting to offer a more elaborated ontological conceptualization of the Maya world, which is the theme of this special issue, my paper calls for a cautious and empirically grounded import of ontological logics like multinaturalism or animism to Mesoamerica or the Andes. While there may be aspects of socio-cosmological logics that are governed by human-animal relations and notions of perspectivism, I doubt that such logics are at the core of the socio-cosmological principles of Mesoamerican or Andean ontologies. Regional specialists must likewise investigate how analogism, as proposed by Descola, will provide a fruitful theoretical framework of Mayan ontology.

My reflection on Isthmo-Colombian ontologies started from two general principles that made the divergence to Amazonian ontologies - based on my own empirical research among the Yukpa - first visible to me. The Yukpa are a Caribspeaking outpost, living in the neighborhood of different Chibcha-speaking groups (Kogi, Ika, Wiwa, Ette, Barí) and the Arawak-speaking Wayuu in the VenezuelanColombian border region. While the Yukpa show typical aspects of Carib-speaking groups, they also interacted with and adopted various characteristics from their Chibchan neighbors. When I tried to apply the animic schemes of identification, it became apparent that the metamorphosis of humans into animals is largely absent and avoided and, if it occurs at all, irreversible. Moreover, there is a continuously reinforced relationship with the dead among the Yukpa that is of outstanding importance (Halbmayer 2013, 2019). The above-mentioned two principles go hand in hand with a third one, namely, that humans and animals have not only different physicalities but also different interiorities and selves.

\section{The avoidance of metamorphosis into animals}

Metamorphosis of humans into animals, which is at the core of Amazonian shamanism and the basis of communication between different human and more than human collectivities, is avoided and, if it occurs, irreversible. Such transgressions of the boundaries between species are mentioned in myths, but hardly form part of contemporary practices. Local myths, in fact, remind people that such trans- 
gression must be avoided. When metamorphosis occurs, it is the outcome of unethical or norm-transgressing behavior (Velásquez Runk et al. 2019) and likely to produce dangerous monstrosity (Halbmayer 2019). It is understood as an irreversible dehumanizing process that ends in disaster (Niño Vargas 2020a). Rather than humans or shamans turning into animals, animals or spirits may appear in human shape to establish contact with humans (Goletz 2020).

\section{Animals as sub-humans}

Human and animals have not just different physicalities but also different interiorities and selves. Animals are commonly seen as personalized but gradually different entities that are potentially able to enter into dialogue and relation with humans, but rarely do so. Animal interiorities are simpler and lack aspects that are constitutional for humans (Martínez Mauri 2019; Niño Vargas 2020a; Velásquez Runk et al. 2019). They are human-like but not identical to humans as they are composed not only of different bodies and substances but also of distinct spiritual aspects. In short, the classical Amazonian multinaturalism along with the spiritual unity and corporal diversity of animism apparently assumes a different character among the groups of the Isthmo-Colombian Area. Animals are lacking the completeness of humans; they were human-like in the mythical past, but are no longer today. This establishes a hierarchy and places animals in a secondary, potentially subhuman position (Niño Vargas 2020a). While human-animal relations may still be important in the context of hunting, for example, it is the relations with deified ancestor-like beings that take center stage in local cosmologies.

\section{Complex relations with the dead}

There is also a special relationship with the dead, sometimes performed in elaborate death rituals and secondary burials (on the Yukpa, see Halbmayer 2013, 2019; on the Wayuu, Perrin 1987; on the Bribri, Bozzoli 1979, Cervantes Gamboa 1990), which contrasts with the paucity of death rituals and the practice of disremembering the dead described for the Amazon (Taylor 1993, see also Chaumeil 2007). In the Isthmo-Colombian area, the dead do not turn into animals, they return to their relatives' villages/houses in the land of the $\mathrm{dead}^{4}$ and must be buried in the earth or in the cemeteries of their families, villages, or clans (Halbmayer 2020d). Thus, we have species-specific cycles and the avoidance of being transformed or eaten by predatory animals on the way to the land of the dead. The arrival in the

4 Which is - in contrast to other parts of Amazonia - also the case in Northwest Amazonia were a "vertical transmission of identities" occurs and there "is an ideal of keeping each system closed, even at the level of exogamic clans: human souls should return to their ancestors' "houses" and be reborn as the same kind of person" (Fausto 2007: 501). 
land of the dead hinges on the life lived and may involve a prolonged period of suffering due to misconduct committed during lifetime and on the ritual support by the living. The dead can be benevolent but also dangerous, if such a transfer cannot take place (Losonczy 2020) or relatives do not provide the necessary support. On the dead persons's journey, an elaborate moral evaluation of their lives takes place, which may delay their arrival in the land of the dead considerably (Halbmayer, under review). All in all, the cycles of transformation between the living and the dead establish "a highly anthropocentric view of the world" (Perrin 1987: 109).

\section{The materialization of thought and substances' spirits}

A next set of principles leads from the observation that human and animals have not only different physicalities but also different interiorities to the observation that a clear separation either between substance and spirit or between physicality and interiority is often missing. Substances may entail spirits and forms of vitality, thoughts may be collected and materialized. Interiorities may thus become materialized, detachable, and transferable and the transmissions of substances may entail the transmission of abilities and knowledge. Animal or plant substances that are inserted into the body of a newborn through the navel change a person's abilities and skills, and an offering of food may either establish relations with the mythical ancestors (Arenas Gómez 2020a) or induce changes in the person. Detachable, transferable, and incorporable elements thus induce gradual changes in the individual's knowledge and abilities. These practices are obviously part of a larger logic concerning the fabrication of the person that is expressed in terms of the incorporation of substances, plants, or body decorations. Of equal importance is the fact that specific substances must not be incorporated but avoided (Martínez Mauri 2019).

\section{Graduated personhood}

Due to the low relevance attached to the physicality/interiority distinction, however, the Amazonian emphasis on the fabrication of the body as a cosmological differentiator appears to shift toward the fabrication of the person through the simultaneous elaboration of body and spirit. The overarching ontological principle seems to be based - not unlike Århem's argument for Southeast Asia - on the logic of "different degrees of spirit/potency, different bodies" that leads to "classes of people [who] are essentially different - different in spirit and therefore different in body" (Århem 2016: 18).

Thus, there are graduated forms of personhood with unequal degrees of similarity in terms of spirit/potency/capacity/bodies. Differences exists between various human and non-human entities of distinct physicalities and interiorities. They may be established through rituals that fabricate more elaborate and capable 
humans by selectively incorporating aspects of the Other, by acquiring elaborate ritualized and often verbalized and musicalized knowledge and/or by connecting the individual to the original entities of creation. Such rituals may entail the so called ombligado among the Waunaan (Velásquez Runk et al. 2019) and Emberá (Losonczy 1986, 1987), Bribri (Bozzoli Vargas 1979: 139-140), baptism among the Iku (Arenas Gómez 2020a), the children's dance among the Yukpa (Halbmayer 2020b), priestly initiation among the Kogi (Reichel-Dolmatoff 1976), or the transmission of knowledge through contacts with non-human beings that appear in human shape among the Yukpa (Goletz 2020).

Graduated forms of difference may also encompass people of different clans and their forms of being. Hierarchically ranked clans (Halbmayer 2020d) can be observed among the Bribri, Cabecar, Iku, Kogi, Wiwa, and Wayuu. Clan members may have exclusive rights to specific knowledge, specific duties, and ritual obligations, and may differ substantially in terms of wealth (for the Wayuu, see Mancuso 2020).

\section{Toward homological forms of identification}

However, the notion of "classes of people [who] are essentially different - different in spirit and therefore different in body" (Århem 2016: 18) relates to totemic rather than analogic logics that involve chains of graduated difference of interiority and physicality. From the very beginning, totemism establishes hybrid collectivities that are divided into various totems, each of them consisting of specific and different kind of beings such as humans, animals, or plants. In terms of continuity and the importance of substance, a (seemingly) totemic mode of identification can be found especially among those groups organized in clans like the Bribri, the Cabecar, the groups of the Sierra Nevada, the U'wa, and the Wayuu.

Among the groups of the Sierra Nevada the prevalent notion is even the explicit idea of the creation of the universe from a single original being. This being is conceptualized as the great mother and identified with the sea and darkness; it existed only in aluna (thought) when the world was still non-existent. Everything originated from this original mother as the only existing entity. Consequently, myths provide a detailed description of the process of the materialization of thought in terms of gestation and a theogenesis of the great mothers' sons, daughters, and grandchildren, of today's spiritual fathers and mothers, their different qualities, and their association with places, the cardinal directions, and human clans.

Beside well-described analogistic features with regard to the temple (Reichel-Dolmatoff 1975), the universe, the human body, the mountains (Reichel-Dolmatoff 1990), the loom and the universe (Reichel-Dolmatoff 1978), or the spindle and the cosmological layers, an all-integrative identity of physicality and interiority exists. Everything emerged from the original mother, their children and chil- 
dren's children, the different clans, to the contemporary humans that are involved in a process of continuing differentiation associated with genealogical distance. The identification with the ancestral parents, by contrast, is assumed as given and permanently recreated. I have called an ontology integrated in this way homological. While "analogical pairs are necessarily ontologically discontinuous, [...] homological pairs are predicated on ontological continuity" (Matthews 2017: 277-278). 'Homology' refers, by contrast to analogy integrated only by similarity, "to characteristics derived from a common phylogenetic origin" (2017: 278).

\section{Humans as plants or seeds}

Humans are generally conceptualized as plants or as having emerged from plants (Kaviany 2020; Niño Vargas 2020a). Humans are often sown as seeds or harvested by gods (on the Bocota, see Peña 1994; on the Bribri, Bozzoli 1979: 167, Kaviany, 2020; on the Ette, Niño Vargas 2008, S. 120; on the Kogi, Reichel-Dolmatoff 1985 [1950-1951]; on the U'wa, Falchetti 2001: 115, 135, 138; Osborn 2009). The god Sabasewa, for example, harvested the first Barí from a pineapple (Castillo 1989: 325-326), the Ngobe sprouted as vegetables (Niño Vargas 2020a: 50, Séptimo und Luz 1986), and the Bribri god Sibö planted humans, or rather the first six human clans, as maize kernels (ditsö). They are today's most important clans and represent the central house post of the Bribri ritual house and universe. The closeness of these clans to the creator establishes a hierarchy where they rank above the other clans. As Niño Vargas argues, among the Chibcha "humanizing movements are thought of as vegetal germination, while dehumanizing movements are understood as animal metamorphoses" (2020a: 55).

However, there may be humans of a different, non-vegetal origin. This seems to be the case with regard to former humanities that still inhabit Chibchan cosmologies of worlds that failed due to cataclysms that were mostly caused by moral misconduct. They are associated with beasts in the contemporary world. Extremely powerful and transformative beings, like the priestly usekar among the Bribri, did not emerge from the maize kernels Sibö planted but had existed already before. They are considered jaguar people (Bozzoli Vargas 1979: 48) and turn into jaguars after death.

\section{Cultivating the world and hierarchical symbiosis with ancestor-like beings}

The world, the universe, and vegetal germination are generally thought about in agricultural terms (Niño Vargas 2020a, 2020b). Agriculture rather than hunting serves as the dominant relational logic that establishes what Niño Vargas and myself have called a hierarchical symbiosis between the one who cultivates and those that are cultivated (Halbmayer 2020c; Niño Vargas, under review). Such a relationship implies central dimensions of agricultural care and includes aspects of 
protection (Descola 2013; Kaviany 2020; Martínez Mauri 2020a), subjection (Martínez Mauri 2020a; Niño Vargas, 2020a), and nourishing/fertilizing the cultivator or the spiritual ancestors (Arenas Gómez 2020a; Kaviany 2020). These relations "operate between terms set in a hierarchy" (Descola 2013: 321) and therefore differ from relations of exchange, gift, and predation that take place between subjects of equal status. In the case of Chibchan groups this hierarchical relation secures cosmological reproduction, and the one who is cared for and protected reciprocates by caring, feeding, and fertilizing those who have provided care. The relationship operates on various levels - between gods and humans, between priests and common people, between the one who cultivates his field and the plants he cares for. By feeding and caring for others, vital relationships are nurtured. A good example of such practices can be found among the Gunas of Panama, who feed the spirit helpers that are manifested themselves in wooden statuettes called nuchugana (Martínez Mauri 2020a, 2020b $)^{5}$ and live with them by smoking them with cocoa and bathing them with aromatic plants, so the spirits care for them. Thus a mutual dependence is established as each entity provides services for the other, which results in a form of identification.

The central relationship thus does not concern a logic of prey and predator but is an asymmetrical relation between "the ancestral parents (...) and their offspring (the I'ku people)" (Arenas Gómez 2020a: 198) and thus a consanguine relation. In the so-called pagamentos, the mamo of the Kogi and Ik'u materialize thoughts and feed the spiritual mothers and fathers. The people deposit their thoughts in the material they offer as food. Nourishment is a primary spiritual force that manifests itself in different forms: food, information, music, bodily substances, communication, or thought. Sacred sites are conscious entities, "mothers and fathers" that sustain the world, but also "think". They "eat" Kogi payments/confessions, but they also "listen" and understand what is said/found to them. At the same time, the obligatory exchange expresses an ecological relationship (Arenas Gómez 2020a, 2020b; Parra Witte 2020). In this way, a hierarchical relation of mutual dependence, a hierarchical mutualism is established. Gods plant humans as seeds and care for them while vice versa humans feed or fertilize the gods to be protected. Although the relationship is hierarchical and asymmetrical, it does not cause differentiation and conflict, but creates identification and relies on establishing an ontological continuity.

Such continuity and interaction are not enabled by metamorphosis but rely on the creation of ontological similarity (Goletz 2020) between ontologically different entities. They rely either on a synchronization of distinct timescapes (Halbmayer 2013, forthcoming) or on ritual co-activity (Pitrou 2016, Goletz, forthcoming) that allows for the transmission of knowledge, substances, and capacities and serves as a functional equivalent to the Amazonian metamorphosis. Among the Kogi, for

5 For an interpretation of the Kuna nuchu that is inspired by Amazonian anthropology, see Fortis 2012. 
example, the relationship with natural phenomena is guided by yuluka ("estar de acuerdo," to agree), by maintaining harmony with and becoming part of the phenomenon or one of its aspects and assuming its characteristics. This "agreement" implies the identification of the individual with the personification (of the great and omnipresent Mother, the Masters or owners, the rain, illnesses, etc.) and its simultaneous neutralization" (Reichel-Dolmatoff 1985: 95).

It has become increasingly clear to me - and may seem obvious to specialists working further north - that such kinds of relations figure prominently in Mesoamerica. They are, for example, present in the identification of maize and humans among the Maya. As Christenson notes,

The creator gods seek to form beings who would be able to take care of them as a parent would supply the needs of his or her children. This reciprocity is fundamental to Maya thought - humans could not exist without the gods nourishing and sustaining them with food, light, and water. At the same time, however, the gods require nourishment as well in the form of prayers, offerings, and properly timed rituals of rebirth. The goal of creation was to create 'true people' who would act as mediators. Through ritual prayers and ceremonies, the gods would be 'sustained,' literally recreated and reborn as they are venerated by humankind. (Christenson 2017: 97)

Among the Maya, the identification of humans with the creator gods is apparently so strong that "the Maya do not worship separable ancestors. They recognize the presence of the ancestors within them. It is part of their blood and their flesh, renewed at each meal by the same maize used to create the first "true people" at the beginning of time. As long as they are alive the ancestors are alive and present", as Christenson notes. "For a Maya to remember a deity or ancestor is to bring him or her forth from his own blood" (2017: 110-111).To the best of my knowledge, no such strong forms of identification are documented for the Isthmo-Colombian area. Deified beings are ancestors with whom humans share physicality and interiority, but they remain distinct beings with whom contact must be established and maintained and who must be nourished. Among contemporary Chibchan-speaking groups humans tend to feed spiritual beings with their own substances (Arenas Gómez 2020a) or the products of their crops. Following such logic, nourishment of ancestor-like deified beings who brought humanity into being does not rely on affinity, exo-cannibalism, or the de-subjectivation of meat. Rather, one cares for and nourishes one's own spiritual parents who, in turn, conceptualize their children as seeds.

\section{Multiple alterities and forms of feeding}

In the Isthmo-Colombian area there is not one single vector of alterity based on symbolic affinity. Alterity includes not only relations to Gods, deities, or spiritual parents, conceived in paternal or maternal terms and as generally benevolent and 
protective beings who figure prominently in cosmologies. Alterity is not a single position of symbolic affinity and the ideal-typical other is not the theriomorph, symbolic affine. In the anthropocentric cosmologies of the Isthmo-Colombian area alterity becomes differentiated and multiplied, with a dominant benevolent relation to ancestor-like deified beings and relations of a different kind to the dead, or specific spirits, animals, or former humanities. The logic of nourishment and feeding may extend beyond the original deified beings to beings who are potentially predatory and dangerous. Nourishment thus becomes a strategy of subjecting and taming the other and keeping the other in a hierarchically subordinate position. The nourishment of potentially dangerous entities that have a symbolic affinal relationship is a way of avoiding predation - and in my understanding, not just a gift but a way of domesticating the spiritual others. Among the Pumé, the women feed the predatory beings with their "bad" (menstrual) blood to keep the cosmos in balance. Through the gift of their blood, the women strive simultaneously to integrate the predatory beings (Orobitg 2020) and to keep them at a distance. Such a domesticating nourishment is, in my opinion, a relation quite different from predatory familiarization (Fausto 1999). In many Isthmo-Colombian societies it is necessary to nourish nonhuman beings in order to sustain a vital balance in the relations with other beings in the cosmos. It is therefore not a relationship of mutual predation and incorporation but one of mediation where aspects that assume the position of nourishment or vitalizing force (be they body substances, songs, agricultural products, hunted meet, or stone powder) are offered to a third party. This logic also encompasses the capture of enemies in order to provide nourishment for the gods among the Aztecs (Köhler 2001; Christenson 2017; Maffie 2019). Maffie, for example, summarizes his findings concerning the Aztecs as follows:

The Mexica see feeding and nurturing as ways of respecting, worshipping, loving, and honoring other beings (creator or otherwise). Such nourishment consists of well-spoken words (what we call 'prayer'), song, dance, music, ceremony, incense, foodstuffs (...), and human or animal blood. The creator beings gift life to (...) humans so that humans will cool, refresh, and rebalance them by nurturing, nourishing, and feeding them in return. (...) Humans (...) are wholly dependent upon creator beings, creator beings themselves are subsequent to creation wholly dependent upon human beings. The continuing existence of creator beings depends essentially upon human nourishing, nurturing, and care. (2019: 62)

\section{From shamanic metamorphosis to priestly synchronization and simila- rization}

Within such a relational logic it is the responsibility of those who are cared for to reciprocate and nourish the father- or mother-like deified figures. It is, in other words, the responsibility of humans to sustain the relationship. Often a specialized priest-like group of people, like the mama among the Kogi or the usekar among 
the Bribri, is in charge of collective and individual rituals to maintain and secure the order of the world. Horizontal Amazonian shamanism with its logic of metamorphosis gives way to vertical forms of shamanism and priesthood. Where shamanism exists in the Isthmo-Colombian area, it therefore tends to be non-metamorphic but mediated by spirits that are controlled and nurtured by the shaman.

The above-mentioned hierarchy between humans and non-humans influences the mode of relationship: it favors offerings and sacrifice over predation, and rather than hunting and metamorphosis, offerings and sacrifices nourish the spiritual beings and establish relations with them. It is a logic that resembles an agricultural rather than a hunting way of appropriation. Following such a logic, perspectivism, when present, also assumes a specific form. It is either selective - as among the Yukpa where perspectivism mainly affects the relation to the collectivity of the long-time dead but not to animals - or perspectivism assumes a specific hierarchical form as identified by Niño Vargas. He states,

Subjection presupposes a positional logic from which a singular perspectivism emerges. The dominant or subordinate position of one entity with respect to another is expressed through the figures of the "cultivator" and the "corn". Humans clearly illustrate the game: although they are "cultivators" from their own perspective, they are "corn" from the perspective of the gods.

The gods see them, not as people, but as grains, while they see the gods, not as equals, but as superior people. Both views establish a hierarchy, although the former emphasizes difference and the latter similarity. Predatory relationships only appear when turning to the alien. Humans see the jungle divinities as hunters and the maize they cultivate as prey. (Niño Vargas, under review)

In that way hierarchical symbiosis encourages the establishment of asymmetrical links that integrate dominant and dominated entities. At the same time, numerous strategies are mobilized to create ontological similarity (Goletz 2020) between different entities (like gods or spirits and humans), synchronicity of different temporal spaces (Halbmayer 2013), ritual co-activity (Pitrou 2016), or by the mentioned agreement yuluka that all allow the transmission of both knowledge and capacities by stressing synchronicity and similarity without relying on the Amazonian metamorphosis.

Viveiros de Castro offers valuable description of such priest-like vertical shamans. They "comprise master-singers and ceremonial specialists, peaceful guardians of an esoteric knowledge indispensable for the reproduction and internal relations of the group (birth, initiation, naming, funerals, etc.)" (2014: 154). While the "archetypal Other of the horizontal shaman is theriomorphic, the Other of vertical shamanism tends to assume the anthropomorphic traits of the ancestor. [...] Vertical shamanism can therefore be linked to the separation of the dead and the animals in two distinct positions of otherness" (2014: 155). Relationships with deified beings and the dead become more important than those with animal spirits. The long-dead 
may even mediate between the living and the spirits as described for the Barí and Wayuu (Halbmayer 2019).

\section{Morality and cosmological temporality}

Such a relational logic implies a specific morality and responsibility toward the dominant entities. Failure to reciprocate causes cosmological consequences and establishes a specific temporality expressed in cataclysms and deteriorating cosmological structures from an origin that is "associated with divinities" to a future that is "an impoverished reflection of present conditions" and related to "the realm of beasts" (Niño Vargas 2020a: 53). Thus temporality is neither an eternal cyclical return nor a flattened or bi-linear multiple time of distinct collectives that converge at specific events such as the hunt (Stolze Lima 1999), but a degenerative process associated with "the fear that humanity will disappear as a result of cataclysms" (Niño Vargas 2020a: 53). Such transfer is embedded in a more general temporal movement from an origin "associated with divinities" to a future that is "an impoverished reflection of present conditions" and "related to the realm of the beasts" (2020a: 53).

Chibchan cosmologies tell of a succession of old aborted humanities; the present cosmos is the result of a series of degrading cataclysms. We thus often find - like in Mesoamerica - the idea of several creations of mankind that came to an end due to humans' moral misconduct. Former or failed humanities may belong to a broad category of beasts, including animals. Such an understanding leads to specific forms of cosmological temporalities, much deeper than in Amazonia and in animism in general, where "time is crushed, flattened, without relief or depth. The mythical events that gave birth to the current state of the world took place a few generations ago at the most and the protagonists are still present. (...) In short, it is a temporality of the instantaneous, unscathed by the weight of history and the memorialization of ancestors" (Descola 2011: 88-89). In contrast to either Mesoamerica or the Andes, however, Isthmo-Colombian cosmological temporalities lack the recurrent cyclical dimension of great changes that are represented even in calendrical time. We see a time marked by deterioration with increasing distance from the original creators and their moral order, a degradation whose prevention is the obligation of humans and part of human ritual activity, especially through priest-like individuals who reestablish the contact, nourish and vitalize the primordial beings.

\section{Conclusion}

All in all, there seems to be a set of principles at work that characterize an Isthmo-Colombian package. The principles include:

1. the avoidance and irreversibility of metamorphosis of humans into animals;

2. animals tend to assume a sub-human position; 
3. species-specific cycles of transformation of the dead who do not transform into animals but join the villages of their deceased relatives;

4. There is no clear separation between substance and spirit or between physicality and interiority. Substances may contain specific forms of spirituality and thoughts may become materialized. This allows for the detachable and transferable transmission of substances, abilities, and knowledge between beings of different kinds.

5. Humans and animals, as well as different graduated forms of human personhood, differ in terms of their physicality and different interiorities and selves;

6. In some areas, like the Sierra Nevada de Santa Marta, homological forms of identification exist.

7. Humans are conceived by the gods as seeds and crops/plants.

8. The principle of hierarchical symbiosis based on a logic of cultivation, agricultural care, and nourishment is of central importance for relations between humans and gods/deified beings/spiritual persons. Instead of a theriomorphic metamorphic horizontal shamanism, priestly hierarchical and harmonizing relations with ancestor-like deified beings are at the center of vertical cosmological relations.

9. Besides the ancestor-like deified beings, relations with other entities exist, which lead to multiple forms of alterity and feeding.

10. Shamanic horizontal metamorphosis into theriomorph others gives way to priestly vertical processes of synchronization and similarization.

11. For the area a specific cosmological temporality seems characteristic marked by the risk of gradual cosmological deterioration that may lead to cataclysms. This temporality is associated with notions of morality and the need to reconnect with the beings of origin or darkness in order to revitalize the world and avoid or slow down dehumanizing transformations. Such a temporality transcends the flat or bilinear Amazonian time as well as the cyclical or even calendrical great transformations of Mesoamerican and Andean ontologies.

While since the 1950s the theoretical framework for the study of contemporary Isthmo-Colombian cultures was - at least with regard to the region's lowlands - provided by Amazonian anthropology, there are, as I have tried to show, significant differences of ontological principles that may not be reduced to the schemes of venatic animism or analogism. It is therefore safe to assume that, while the empirically grounded debate of ontological principles from other areas, in our case from Amazonia, may produce creative theoretical proposals, an uncritical import of such ontological schemes is highly suspect of creating selective misreadings and biased interpretations. For the Isthmo-Colombian Area, efforts have been made in recent years to correct such misinterpretations and identify ontological principles at work in the area. When introducing the ontological turn to Maya anthropology and archeology, which is the aim of this special issue, it seems important to rethink local 
principles in ontological terms and avoid the imposition of theoretically attractive, but only partially fitting ontological schemata, as such a procedure might produce systematically selective misinterpretations of local ontological principles.

\section{References}

Arenas Gómez, Jose

2020a Parents Who Own Lives: Relations and Persons among the I'ku, a Chibchan Group in Colombia. In Amerindian Socio-Cosmologies between the Andes, Amazonia and Mesoamerica: Toward an Anthropological Understanding of the Isthmo-Colombian Are edited by Ernst Halbmayer, pp. 181-204. Routledge, London and New York.

2020b Vitalidades en flujo: de pagar, ofrendar y alimentar a los seres del origen entre la gente Iku. Tabula Rasa 36: 73-99.

Århem, Kaj

2016 South Asian Animism in Context. In Animism in South-East Asia, edited by Kaj Århem and Guido Sprenger, pp. 3-30. Abingdon \& New York, Routledge.

Bozzoli Vargas, M. E.

1979 El nacimiento y la muerte entre los Bribris, Editorial de la Universidad de Costa Rica, San José.

Castillo, Dionisio

1989 Mito y sociedad en los Barí. Amurú Ediciones, Salamaca.

Cervantes Gamboa, Laura

1990 Sular-Playing for the Dead: A Study of Bribri Funerary Chants as Speech Acts. MA thesis, State University of New York, Albany.

Chaumeil, Jean-Pierre

2007 Bones, flutes, and the dead. Memory and funerary treatments in Amazonia. In: Time and Memory in Indigenous Amazonia. Anthropological perspectives, edited by Carlos Fausto und Michael Heckenberger, p. 243-283. University Press of Florida, Gainesville. Christenson, Allen J.

2017 "Who Shall Be a Sustainer?": Maize and Human Mediation in the Maya Popol Vuh. In Global History of Literature and the Environment, edited by John Parham and Louise H. Westling, pp. 93-106. Cambridge University Press, Cambridge.

Constenla Umaña, A.

1991 as Lenguas del Área Intermedia: Introducción a su Estudio Areal. Editorial de la Universidad de Costa Rica, San José.

2012 Chibchan Languages. In The Indigenous Languages of South America: A Comprehensive Guide, edited by Lyle Campbell and Verónica Grondona, pp. 391-439. Mouton de Gruyter, Berlin

Descola, Philippe

2011 Lécologie des autres: l'anthropologie et la question de la nature. Quae, Versailles.

2013 Beyond Nature and Culture. University of Chicago Press, Chicago.

Drennan, R. and C. Uribe (editors)

1987 Chiefdoms in the Americas. University Press of America, Lanham.

Drennan, Robert D.

1995 Chiefdoms in Northern South America. Journal of World Prehistory 9 (3): 301-340. 
Falchetti, Ana María

2001 The Transformation of the Seed: Ritual Offerings and Trade among the Uwa of Colombia. Journal of Latin American Lore 21 (1): 109-142.

Fausto, Carlos

1999 Of enemies and Pets: Warfare and Shamanism in Amazonia. American Ethnologist 26 (4): 933-956.

Fortis, Paolo

2012 Kuna Art and Shamanism: An Ethnographic Approach. University of Texas Press, Austin.

Geurds, Alexander and Laura N. K. van Broekhoven

2010 The Similarity Trap: Engineering the Greater-Caribbean, a Perspective from the Isthmo-Colombian Area. Journal of Caribbean Archaeology 3: 52-75.

Goletz, Anne

2020 Receiving the Armadillo's Song: Oneiric Knowledge Transmission Between an Armadillo and a Wise Woman in Sokorpa, Yukpa Territory in Northern Colombia. Tabula Rasa (36): 267-292.

Haberland, Wolfgang

1957 Black-on-Red Painted Ware and Associated Features in the Intermediate Area. Ethnos 22 (3-4): 148-161.

Halbmayer, Ernst

(under review): "Dying" and the Moral Judgement of Life: Cosmology, Obstacles and Support on the Long Way to a New Life among Chibchan-speaking Groups. In Universos chibchas. Nuevas aproximaciones a la unidad y la diversidad humana del área istmo-colombiana, edited by Niño Vargas, Juan Camilo and Stephen Beckerman, Ediciones Uni Andes, Bogotá.

2010 Kosmos und Kommunikation. Weltkonzeptionen in der südamerikanischen Sprachfamilie der Cariben. Facultas Verlag, Wien.

2012 Amerindian Mereology: Animism, Analogy, and the Multiverse. Indiana 29: 103-126.

2013 Securing a Life for the Dead among the Yukpa: The Exhumation Ritual as a Temporary Synchronization of Worlds. Journal de la Société des Américanistes 99 (1): 105-140.

2019 Amerindian Sociocosmologies of Northwestern South America: Some Reflections on the Dead, Metamorphosis, and Religious Specialists 1. Journal of Latin American and Caribbean Anthropology 24 (1): 13-31.

2020a Amerindian Socio-Cosmologies between the Andes, Amazonia and Mesoamerica: Toward an Anthropological Understanding of the Isthmo-Colombian Area. Routledge, London and New York.

2020b Bailando recién nacidos, sometiendo enemigos, formando guerreros: el baile del niño como fuente de fuerza, vitalidad, y resistencia entre los yukpa. Tabula Rasa 36: 293-320.

2020c Introduction: Toward an Anthropological Understanding of the Area between the Andes, Mesoamerica, and the Amazon. En Amerindian Socio-Cosmologies between the Andes, Amazonia and Mesoamerica: Toward an Anthropological Understanding of the Isthmo-Colombian Area, edited by Ernst Halbmayer, pp. 3-33. Routledge, London and New York.

2020d Kinship, Clanship, and Hierarchy in the Isthmo-Colombian Area. In Amerindian Socio-Cosmologies between the Andes, Amazonia and Mesoamerica: Toward an An- 
thropological Understanding of the Isthmo-Colombian Area, edited by Ernst Halbmayer, pp. 88-122. Routledge, London and New York.

Helms, Mary W.

1980 Succession to High Office in Pre-Columbian Circum-Caribbean Chiefdoms. Man (N.S.) 15(4): 718-731.

1992 Cosmovision of the Chiefdoms of the Isthmus of Panama. In The Ancient Americas: Art from Sacred Landscapes, edited by Richard F. Townsend pp. 217-228, Prestel Verlag, Munich.

Hill, Jonathan D. and Fernando Santos-Granero (editors)

2002 Comparative Arawakan Histories: Rethinking Language Family and Culture Area in Amazonia. University of Illinois Press, Urbana.

Hofman, Corinne L., Alistair J. Bright, R. Rodríguez Ramos, Recinto de Utuado and P. de Ciencias Sociales

2010 Crossing the Caribbean Sea: towards a Holistic View of Pre-Colonial Mobility and Exchange. Journal of Caribbean Archaeology 3: 1-18.

Hoopes, John W. and Oscar M. Fonseca Z.

2003 Goldwork and Chibchan identity: Endogenous Change and Diffuse Unity in the Isthmo-Colombian Area. I): In Gold and Power in Ancient Costa Rica, Panama, and Colombia. A Symposium at Dumbarton Oaks, 9 and 10 October 1999, edited by Jeffrey Quilter and John W. Hoopes, pp. 49-90. D.C: Dumbarton Oaks Research Library and Collections, Washington.

Kaviany, Schabnam

2020 Plant Ontologies among the Bribri of Talamanca, Costa Rica. In Amerindian SocioCosmologies between the Andes, Amazonia and Mesoamerica: Toward an Anthropological Understanding of the Isthmo-Colombian Area, edited by Ernst Halbmayer, pp. 279-302. Routledge, London and New York.

Keegan, William F. and Morgan D. MacLachlan

1989 The Evolution of Avunculocal Chiefdoms: A Reconstruction of Taino Kinship and Politics. American Anthropologist 91: 613-630.

Kirchhoff, Paul

1943 Mesoamerica. Sus limites geográficos, composicón étnica y carateres culturales. Acta Americana 1: 92-107.

Köhler, Ulrich

2001 "Debt-payment" to the Gods among the Aztec: the Misrendering of a Spanish expression and its Effects. Estudios de cultura Náhuatl 32.

Kurella, Doris

1993 Handel und soziale Organisation im vorspanischen nördlichen Andenraum: zur politischen Ökonomie subandiner Häuptlingstümer im Gebiet des ehemaligen Nuevo Reino de Granada vor der Eroberung durch die Spanier im frühen 16. Jahrhundert. Holos, Bonn.

1998 The Muisca: Chiefdoms in Transition. In Chiefdoms and Chieftaincy in the Americas, edited by Elsa M. Redmond, pp. 189-216. University of Florida Press, Gainesville.

Langebaek, Carl Henrik

2005 The Pre-Hispanic Population of the Santa Marta Bays: a Contribution to the Study of the Development of the Northern Colombian Tairona Chiefdoms. University of Pittsburgh: Center for Comparative Archaeology, Pittsburgh. 
Losonczy, Anne Marie

2020 Murderous Spirits: Shamanic Interpretation of Armed Violence, Suicide, and Exhumation in the Economy of Death of the Emberá (Chocó, Antioquia, Colombia). In Amerindian Socio-Cosmologies between the Andes, Amazonia and Mesoamerica: Toward an Anthropological Understanding of the Isthmo-Colombian Area, edited by Ernst Halbmayer, pp. 330-344. Routledge, London and New York.

1986 La sagesse el le nombril. Rites de naissance et sages-femmes chez les Embera et les Afro-Colombiens du Haut-Choco (Colombie). Civilisations 36 (1/2): 259-287.

1987 Le nom et l'origine: Constitution de l'identité individuelle chez les Embera du Choco. Civilisations 37 (2): 229-247.

Maffie, James

2019 The Nature of Mexica Ethics. In Comparative Metaethics: Neglected Perspectives on the Foundations of Morality, edited by Colin Marshall, pp. 60-80,. Routledge London and New York.

Mancuso, Alessandro

2020 The place of Livestock in Human-Nonhuman Relationship among the Wayuu. In Amerindian Socio-Cosmologies between the Andes, Amazonia and Mesoamerica: Toward an Anthropological Understanding of the Isthmo-Colombian Area. London and New York: Routledge, pp. 303-329.

Martínez Mauri, Mònica

2019 What Makes the Gunas Dules? Reflections on the Interiority and the Physicality of People, Humans, and Nonhumans. Journal of Latin American and Caribbean Anthropology 24 (1): 52-69.

2020a Things, Life, and Humans in Guna Yala (Panama): Talking about molagana and nudsugana inside and outside Guna Society. In Amerindian Socio-Cosmologies between the Andes, Amazonia and Mesoamerica: Toward an Anthropological Understanding of the Isthmo-Colombian Area, edited by Ernst Halbmayer, pp. 257-278. Routledge, London and New York.

2020b Trocas entre os humanos e as árvores na região istmo-colombiana. Contribuições etnográficas desde Gunayala (Panamá). Tabula Rasa 36: 131-149.

Martínez Mauri, Mònica and Ernst Halbmayer (editors)

2020 Ofrendas, intercambios y otros modos de relación en las socio-cosmologías indígenas contemporáneas del área istmo-colombiana. Tabula Rasa 36 (Special Issue): 19-320.

Matthews, William

2017 Ontology with Chinese Characteristics: Homology as a Mode of Identification. HAU: Journal of Ethnographic Theory 7 (1): 265-285.

Murra, John

1972 El control vertical de un máximo de pisos ecológicos en las sociedades andinas. In Formaciones ecoómicas y politicas del mundo andino, edited by John Murra, pp. 59-115. Instituto de Estudios Peruanos, Lima.

Needham, Rodney

1975 Polythetic Classification: Convergence and Consequences. Man (N.S.) 10: 349369. 
Niño Vargas, Juan Camilo under review El universo cultivado. Humanidad y agricultura en los cosmos chibchas. In Universos chibchas. Nuevas aproximaciones a la unidad y la diversidad humana del área istmo-colombiana, edited by Niño Vargas, Juan Camilo and Stephen Beckerman, Ediciones Uni Andes, Bogotá.

2008 Ciclos de destrucción y regeneración: experiencia histórica entre los ette del norte de Colombia. Historia Crítica 35: 105-129.

2018 Cosmos Ette. Ethnographie d'un univers du Nord de la Colombie. Ph.D Thesis. École des hautes études en sciences sociales, Paris.

2020a An Amerindian Humanism: Order and Transformation in Chibchan Universes. In Amerindian Socio-Cosmologies between the Andes, Amazonia and Mesoamerica: Toward an Anthropological Understanding of the Isthmo-Colombian Area, edited by Ernst Halbmayer, pp. 37-60. Routledge, London and New York.

2020b La división cósmica de las labores terrenales. Interacción entre humanos y no-humanos en los campos de cultivo ette. Tabula Rasa 36: 45-71.

Orobitg, Gemma

2020 Sangre y lógica del don entre los indígenas pumé de Venezuela. Un modelo femenino del cosmos. Tabula Rasa 36: 223-245.

Osborn, Ann

1988 El multiculturalismo en los Andes Orientales. Revista de Antropología 4 (2): 23-42.

2009 The Four Seasons of the U'wa: A Chibcha Ritual Ecology in the Colombian Andes. Sean Kingston, Wantage.

Oyuela-Caycedo, Augusto

2008 Late Pre-Hispanic Chiefdoms of Northern Colombia and the Formation of Anthropogenetic Landscapes. In Handbook of South American Archeology, edited by Helaine Silverman and William H. Isbell, pp. 405-428. Springer New York.

Peña, Enrique Margery

1994 Mitología de los bocotás de Chiriquí. Ediciones Abya-Yala, Quito.

Perrin, Michel

1987 The Way of the Dead Indians: Guajiro Myths and Symbols.: University of Texas Press, Austin.

Pitrou, Perig

2016 Co-activity in Mesoamerica and in the Andes. Journal of Anthropological Research 72 (4): 465-482.

Redmond, Elsa M. (editor)

1998 Chiefdoms and Chieftaincy in the Americas. University of Florida Press, Gainesville.

Reichel-Dolmatoff, Gerardo

1975 Templos kogi. Introducción al simbolismo y a la astronomía del espacio sagrado. Revista Colombiana de Antropología 19: 199-245.

1976 Training for the Priesthood among the Kogi of Colombia. En Enculturation in Latin America: An Anthology (Latin American Studies Series and Latin American Studies, 37), edited by Johannes Wilbert, pp. 265-288. UCLA Latin American Center Publications, University of California, Los Angeles.

1978 The Loom of Life: A Kogi Principle of Integration. Journal of Latin American Lore 4 (1): 5-27. 
1985 Los Kogi. Una tribu de la Sierra Nevada de Santa Marta, Colombia. Procultura (Nueva biblioteca colombiana de cultura, 2), Bogotá.

1990 The sacred Mountain of Colombia's Kogi Indians. Brill, Leiden.

Séptimo, Roger and G. Joly Luz

1986 Sucesos antiguos dichos en Guaymí. Asociación Panameña de Antropología, Panamá. Steward, Julian H. (editor)

1948 Handbook of South American Indians. Vol. 4: The Circum-Caribbean Tribes. Smithsonian Institution, Washington.

Steward, Julian H. and Louis C. Faron (editores)

1959 Native Peoples of South America.: McGray-Hill, New York, Toronto and London.

Stolze Lima, Tânia

1999 The Two and its Many: Reflections on Perspectivism in a Tupi Cosmology. Ethnos 64 (1): 107-131.

Taylor, Anne-Christine

1993 Remembering to Forget: Identity, Mourning and Memory among the Jivaro. Man (N.S.) 28 (4): 653-678.

Velásquez Runk, Julie, Chindío Peña Ismare and Toño Peña Conquista

2019 Animal Transference and Transformation Among Wounaan. Journal of Latin American and Caribbean Anthropology 24 (1): 32-51.

Viveiros de Castro, Eduardo B.

1998 Cosmological Deixis and Amerindian Perspectivism. Journal of the Royal anthropological Institute (N.S.) 4 (3): 469-488.

2001 GUT Feelings about Amazonia: Potential Affinity and the Construction of Sociality. In Beyond the Visible and the Material, edited by Laura M. Rival and Neil L. Whitehead, pp. 19-44. Oxford University Press, Oxford and New York.

2014 Cannibal Metaphysics. University of Minnesota Press (Univocal Series), Minneapolis.

Willey, Gordon R.

1971 An Introduction to American Archaeology: Vol. 2: South America. Englewood Cliffs, NJ: Prentice-Hall.

Wissler, Clark

1922 The American Indian: An introduction to the Anthropology of the New World. Oxford University Press Oxford and New York.

Witte, Falk Parra

2020 A estrutura que sustenta a vida: alimento e intercâmbio entre os Kogi. Tabula Rasa 36: 101-129. 